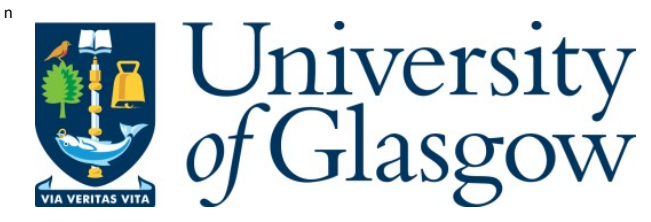

A skins, K . (2014) A quiet politics of being together: M iriam and

Rose. A rea, 46 (4). pp. 353-354. ISSN 0004-0894

Copyright @ 2014 Wiley

A copy can be downloaded for personal non-commercial research or study, without prior permission or charge

Content must not be changed in any way or reproduced in any format or medium without the formal permission of the copyright holder(s)

http://eprints.gla.ac.uk/99955/

Deposited on: 27 N ovember 2014

Enlighten - Research publications by members of the University of Glasgow http://eprints.gla.ac.uk 


\title{
5. A quiet politics of being together: Miriam and Rose
}

\begin{abstract}
This essay draws on fieldwork with a befriending scheme that pairs refugees, asylum seekers and local residents in the north east of England. It explores the ways in which a 'quiet politics' of encounter, embedded in intimate relationships, is caught up in and productive of complex inter-scale geographies, highlighting the ebbs and flows across security and insecurity. Critically, it foregrounds the relationality of emotions in enabling and maintaining intimate-geopolitics.
\end{abstract}

\section{Keywords}

emotions, intercultural encounter, geopolitics

This essay foregrounds a quiet politics that is enacted in initiating interpersonal relationships, while simultaneously caught up with/in wider geopolitics, and interwoven through scale: a quiet politics about belonging, about local community; interconnected through international mobilities and working to connect across difference. Emphasising the role of emotions in forms of caring, as central to developing relationships and also brought to them from other places and times, I argue that emotionality both mobilises the quiet politics that bring people together, and is inherent in their being together: 'the intimate as foundational to and within other realms' (Pain and Staeheli this issue). I draw on a specific relationship to exemplify the broader framing of intimacy-geopolitics set out in the introduction.

Miriam and Rose are two women who have become friends over the past three years, through a scheme that pairs longer term residents with refugees and asylum seekers in Newcastle-upon-Tyne, north east England ${ }^{1}$. Miriam is a refugee from Iraq, who came to the UK four years ago. She stayed in her home country longer than she would have wished, to 
care for her elderly mother, fleeing with her children only after her mother died. Miriam comes to the scheme articulating a desire to belong in Newcastle, to be part of the local community, to build connections with people in Newcastle. Rose is a retired nurse, who worked overseas, mostly in Asia, and has difficult and fond memories of these experiences. Rose comes to the scheme wanting to reciprocate the welcome she received elsewhere in the world, speaking of belonging to a wider/global community. While we must be aware of the privilege of certain mobilities over others, and the power relations enabling such movements, critical here is that Rose desires a more open and inclusive local community in Newcastle.

Both women, then, evidence intimate-geopolitics as asset of spatial relations, coming together through embodied emotions from elsewhere, their relationship produced through a quiet politics - an unassuming praxis of engaging with others, in which new social relations are built in/through everyday places, relationally connected across a range of geographies (Askins forthcoming). Both women sought out the scheme to (re)produce a specific localityfuture, performing a citizenry embedded in emotional belongings, previous experiences and their own sense of agency. In particular, Miriam moves beyond "performing the script of 'refugee'" (Hyndman 2010: 456), enacting a will to engagement with local people, disrupting how those constructed as needing 'welcome' and/or 'care' may be reiterated as power-less (Korf 2007).

About a year ago, Rose's husband died. Her family returned home for the funeral, but live elsewhere in the UK. Miriam has been with Rose through the longer bereavement process, visiting and bringing food, going out shopping with her, sitting and talking with her - as Rose had done with Miriam in the preceding couple of years, when Miriam first arrived in the UK grieving her mother. This resonates with Wiles' (2011) conceptualisation of vulnerability as enabling an openness through which alternative relations may be performed in positive ways, not always already fragile and weak. Miriam's vulnerability and need for security is not reducible to only being in need. Neither is Rose's.

Rather, over the past three years, they have formed close bonds. Miriam describes Rose as 'being like a mother to me, and a grandmother to my children'. Rose describes Miriam as being a great support at a difficult time, 'like a daughter to me'. These women connect 
through an emotional and embodied mode of interaction: gentle hands on shoulders, smiles, laughter, tears and frustrations. Emotions are not always positive and easy, and not always shared: key is that emotionality per se (being emotional/having emotions) is central to their relationship. What is important here is that emotions are embedded through Miriam and Rose's friendship from before they met, and enter their intimacy from other places. Past/distant violences are part of refugees' and asylum seekers' everyday lives, and Rose, too, brings embodied emotions to the relationship from other places at other times. When we consider intimacy, then, we should "highlight its shifting and multiple scope across transnational lives, ordinary spaces and daily interactions" (Dennis and Warin 2010: 50).

This unfolding friendship - and there are many others across the scheme - foregrounds how intimate relationships, as a set of mutually caring practices, persist precisely because they are simultaneously rooted at other scales. It works to challenge local exclusionary discourses embedded in current dominant UK government anti-immigration rhetoric (Conlon and Gill 2013), resisting hegemonic geopolitics and enacting an emotional citizenry as (potentially) part of wider transformative change, diffusing back out from the local. Rose and Miriam demonstrate the importance of researching intimate relationships, their quiet politics and embodied (re)productions of place, as part of critical geopolitics scholarship that challenges violence and insecurity. This recognises geopolitics as inherently intimate, in the fuller sense of intersecting intimacy that Pain and Staeheli describe (this issue). Rose and Miriam are actively co-constructing securities through reciprocal care, in a profoundly feminist sense (Beasley and Bacchi 2007). This remains fragile, emergent, powerful and hopeful, exemplifying intimacy-geopolitics as quietly calling forward interconnections across the local, national and global, and public and private space.

${ }^{1}$ This 'befriending' scheme centres around partnered individuals spending time together in ways that best suit them, run through a local voluntary organisation, and the focus of ongoing participatory research since 2010.

\section{References}


Askins K (forthcoming) Being together: everyday geographies and the quiet politics of belonging ACME: An International E-Journal for Critical Geographies

Beasley C and Bacchi C 2007 Envisaging a new politics for an ethical future: beyond trust, care and generosity towards an ethic of 'social flesh' Feminist Theory 8 3279-298

Conlon D and Gill N 2013 Gagging orders: asylum seekers and paradoxes of freedom and protest in liberal society Citizenship Studies 172 241-259

Dennis S and Warin M 2010 Honeyed tongues and hostile intimacy: engaging trauma across migrant worlds Emotion, Space and Society 3 50-55

Hyndman J 2010 Introduction: the feminist politics of refugee migration Gender, Place and Culture $17 \quad 4$ 453-459

Korf B 2007 Antinomies of generosity: moral geographies and post-tsunami aid in Southeast Asia Geoforum 382 366-378

Wiles J 2011 Reflections on being a recipient of care: vexing the concept of vulnerability Social and Cultural Geography 126 573-588 